\title{
Application of 3D seismic attributes and seismic geomorphology on a slope system of the southern Colombian Caribbean margin
}

Esteban Alfaro ${ }^{1 *} ;$ Michael Holz ${ }^{1}$.

${ }^{1}$ GETA / Grupo de estratigrafia teórica e aplicada - Universidade Federal da Bahia

Copyright 2014, SBGf - Sociedade Brasileira de Geofísica

Este texto foi preparado para a apresentação no VI Simpósio Brasileiro de Geofísica, Porto Alegre, 14 a 16 de outubro de 2014. Seu conteúdo foi revisado pelo Comitê Técnico do VI SimBGf, mas não necessariamente representa a opinião da SBGf ou de seus associados. É proibida a reprodução total ou parcial deste material para propósitos comerciais sem prévia autorização da SBGf.

\begin{abstract}
South Caribbean margin has been dominated by gravitydriven processes, which are important agents for transporting sediments downslope into deep-marine environments. We have characterized the Pliocene to Holocene offshore succession of the Colombian Caribbean margin and its stratigraphic distribution using 3D seismic data and seismic attributes. Nine stratigraphic intervals were characterized within the study, and are interpreted to consist of a range of seismic geomorphologies, including slumps, turbidites and debrites. Slumps display high-amplitude, high-continuity, lobate and confined morphologies. We founded sufficient evidence which reveals that gravity sedimentary processes have been controlled by faulting and mud diapirism.
\end{abstract}

\section{Introduction}

Submarine slopes are frequently composed of gravitydriven deposits (Maslin et al., 2004; Newton et al., 2004). The causes of intense gravity-driven sedimentation on the continental slopes include relative base level changes and syn-sedimentary tectonics causing mud diapirism which results in the creation of inter- and intra-basinal bathymetry (McGilvery and Cook, 2003).

The morphology of the Colombian Caribbean margin and its sedimentation patterns have been studied since the fifties by Duque-Caro (1990); Romero-Otero et al. (2010) and Vinnels et al. (2010). Romero-Otero et al. (2010) using multi-beam bathymetry, side-scan sonar images and 2D seismic profiles, identified a series of Miocene to recent detached and shelf attached mass transport complexes in the Magdalena Fan. The 3D seismic data allow us to get a more detailed understanding of architecture associated to these deposits from which process based interpretations were developed. The seismic volume and the high stratigraphic and structural definition provided by seismic attribute analysis allowed us to interpret nine gravity-driven sedimentary events, revealing its geomorphological elements from palaeoshelf break to intraslope.

\section{Study area}

The area is controlled by the interaction between Andean Orogeny, the Caribbean, South American, Nazca and Cocos plates and the Panama Arc (Giunta et al., 2001; Cediel et al., 2003) (Figure 1).

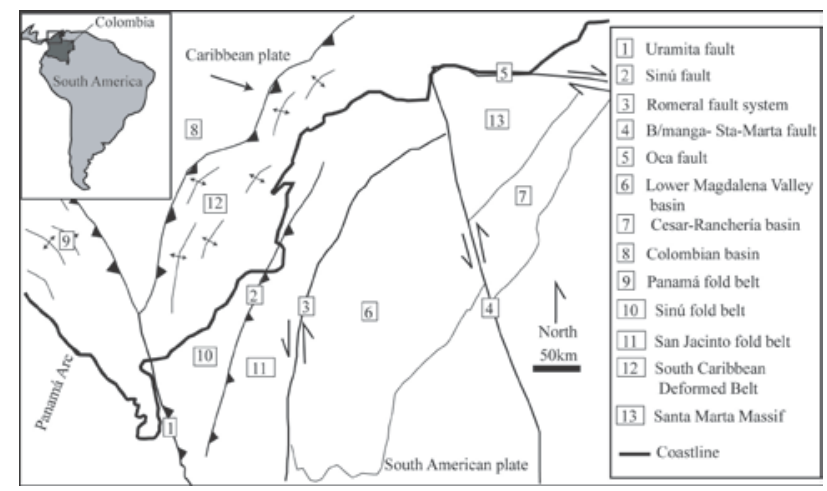

Figure 1 - Map of the northwestern Colombian Caribbean margin showing the location of the study area.

Transpression is evident, forming fold belts and relay structures which still active (Rossello, 2007; Bermudez, et al., 2009). The Colombian Caribbean area has been relatively unexplored. Oil seeps are seen across the southern Caribbean Basin. Channel-levee complexes, confined and unconfined channel-lobe complexes have been interpreted as the more important reservoirs.

\section{Methodology}

The principal data of this study is a high-quality 3D PSTM seismic volume provided by Ecopetrol. The seismic data was acquired in water depths that range from 60 to 1300 $\mathrm{m}$. Its processing sequence included a 3D-pre-stack time migration with sampling rate every $4 \mathrm{~ms}$. The interpretation methodology is based on a seismic geomorphologic approach through standard seismic interpretation workflows. Structural, stratigraphical and morphological features were interpreted from key timeslices. That covered the widest range of visualization and included top and basal boundaries of each gravitydriven deposit unit. We used similarity, amplitude and complex trace attributes to derive four seismic facies (Table 1). Angles of fault plane associated to slumprelated thrusts were calculated using seismic velocities extracted from a sonic log in one well.

Gravity-driven deposits consist of mass transport complexes (MTCs) and turbidity currents, where, mass transport complexes can be classified as slides, slumps 
or debris-flow deposits (debrites) (Dott, 1963; Nardin et al., 1979; Moscardelli et al., 2006). A slide represents a coherent translational mass transport of a block or strata on a planar glide plane (shear surface) without internal deformation (Moscardelli and Wood, 2007). A slump is a coherent mass of sediment that moves on a concave-up glide plane and undergoes rotational movements causing internal deformation (Shanmugam, 2006; Moscardelli and Wood, 2007). Seismic interpretation using similarity, amplitude and complex trace attributes calibrated with seismic profile along key timeslices, reveals high degree of confinement of MTCs.

\section{Results}

We identified four stratified slump bodies varies in a range from 70 to $350 \mathrm{~m}$ in thickness and 3 to $35 \mathrm{~km}^{2}$ in area. Slump deposits show depositional thrust systems. These systems occur along multiple frontal ramps (Figure 2). In map view, this faulting is evident along curvilinear reflections that are getting out from a common point associated to the source zone or headwall zone.

The oldest slump that has been identified in this study has an elongated lobate morphology lying over a broad area. Their lateral boundary is characterized by a wavy edge with high confinement, which has been associated to geometry of a wide north-south syncline. Two seismic facies SF1 and SF2 are distinct in the slumping systems. Complex trace seismic attribute reveals chaotic seismic facies in these units (Figure 3).

Similarity seismic attribute in the sea floor horizon allowed defining four mixed slumps-turbidites-debrites deposits or MSTDs. These bodies has been mainly identified by lobate morphologies and mottled appearance in the upper slope system (Figure 4). Similarity attribute illuminated incised channels with linear morphology, escarpments, linear ridges and mud diapirs associated to same upper slope system. In contrast with the slumps and debrites previously documented, the mixed slumps-turbiditesdebrites are not neither structurally encased nor frontally confined.

The main mixed slumps-turbidites-debrites corresponds to a channelized and undeformed lobe where the bulk of this unit is concentrate. The boundaries of this unit are defined by a high contrast of similarity associated with different facies in the outside area. The lobe has a maximum length of $11 \mathrm{~km}$ and its width is progressively increasing from $2.1 \mathrm{~km}$ in the south to $7.2 \mathrm{~km}$ in the north. According to our interpretation, the basal surface of this unit is related to a cannibalization process associated to an ancient incised canyon which acted through shelfbreak region. Subsequently, the canyon was abandoned and multi episodic gravity-driven sedimentation took place. This deposit is composed of a relatively conformable succession of slumps, turbidites and debrites. The main erosional marks observed are small scours that have been associated to cutting processes during depositional thrusting in the basal surface of slumps. The imprint of the erosional features has an irregular morphology in the basal surfaces of slump deposits.

\section{Discussion and conclusions}

Slumps and debrites are located along axis of wide synclines between high-angle and mud-cored periclines which suggest a high confinement. We suggest that oversteepening related to mud diapirism was the main triggering mechanism to initiate the slumping and debrisflowing events. We can conclude that:

- Geomorphological seismic interpretation and seismic attributes analysis in three-dimensional high-quality seismic data provided an excellent opportunity to characterize depositional systems in an intraslope sub-basin

- Local over-steepening related to mud diapirism was the main triggering mechanism to initiate the gravity-driven deposits associated to slumping and debris-flowing events

- Application of seismic attributes and geomorphological seismic interpretation should be considered as an important tool to define potential traps, characterize reservoirs and seals and handle geohazards during drilling operations.

\section{Acknowledgements}

The authors acknowledge Ecopetrol for supplying the seismic and well data which made the present study possible. Esteban Alfaro thanks Brazilian agency CAPES for Ph. D scholarship. Michael Holz acknowledges the Brazilian agency CNPq for personal research grant (PQ 303047/11-9). We acknowledge CPGG (Centro de Pesquisa em Geofísica e Geologia) from Universidade Federal da Bahia.

\section{References}

Bermudez, H. D., Alvarán, M., Grajales, J. A., Restrepo, L. C., Rosero, J. S., Guzman, C., Ruiz, E. C., Navarrete, R. E., Jaramillo, C., Osorno, J. F., 2009. Estratigrafía y evolución geológica de la secuencia sedimentaria del Cinturón Plegado de San Jacinto. Memorias XII Congreso Colombiano de Geologia.

Cediel, F., Shaw, R., Cáceres, C., 2003. Tectonic Assembly of the Northern Andean Block. In: Bartolini, C., Buffler, R.T., Blickwede, J. (eds.), The Circum-Gulf of Mexico and the Caribbean: Hydrocarbon Habitats, Basin 
Formation, and Plate Tectonics. AAPG Memoir 79, pp. 815-848.

Dott, R. H., 1963. Dynamics of subaqueous gravity depositional processes. Bulletin of the American Association of Petroleum Geologists, vol. 47, no. 1, 104128

Duque-Caro, H., 1990. Neogene stratigraphy, paleoceanography and paleobiogeography in northwest South America and the evolution of the Panama seaway. Paleogeography. Paleoclimatology. Paleoecololgy 77, 203-234

Giunta, G., Beccaluva, L., Coltori, M., Siena, F., Mortellaro, D., Cutrupia, D., 2001. Structure, tectonomagmatic setting of the Peri-Caribbean Ophiolites, and geodynamic implications. Fed. Italiana Scienze della Terra "Geoitalia '01".

Maslin, M., M. Owen, S. Day, D. Long, 2004, Linking continental-slope failures and climate change: Testing the clathrate gun hypothesis: Geology, v. 32, 1, $53-56$.

McGilvery, T.A., and Cook, D.L., 2003. The influence of local gradients on accommodation space and linked depositional elements across a stepped slope profile, Offshore Brunei. Shelf margin deltas and linked down slope petroleum systems: global significance and future exploration potential, GCSSEMP Foundation 23rd Annual Bob F. Perkins Research Conference, Extended Abstracts Volume, 387-419

Moscardelli, L., Wood, L., Mann, P., 2006. Mass-transport complexes and associated processes in the offshore area of Trinidad and Venezuela. The American Association of Petroleum Geologists. Bulletin, vol. 90, no. 7, pp. 10591088.

Moscardelli, L., Wood, L., 2007. New classification system for mass transport complexes in offshore Trinidad. Basin Research, 1-26

Nardin, T. R., Hein, F. J., Gorsline, D. S., Edwards, B. D., 1979. A review of mass movement processes, sediment and acoustic characteristics, and contrasts in slope and base-of-slope systems versus canyon-fan-basin floor systems. The Society of Economic Paleontologists and Mineralogists (SEPM) Special Publication, no. 27, 61-73.

Newton, C., G. Wach, U. Dalhousie, C. Shipp, D. Mosher, 2004, Importance of mass transport complexes in the Quaternary development of the Nile fan, Egypt: Annual
Offshore Technology Conference, Houston, Texas, OTC Paper 16742, 10 pp.

Romero-Otero, G. A., Slatt, R. M., Pirmez, C., 2010. Detached and Shelf-Attached Mass Transport Complexes on the Magdalena Deepwater Fan. In D.C. Mosher et al. (eds.), Submarine Mass Movement and Their Consequences, Advances in Natural and Technological Hazards Research, vol. 28, 593-606.

Rossello, E., 2007. El margen Caribeño Colombiano: Un balance dinámico de escenarios tectosedimentarios pasivos y transpresivos, XI Congreso Colombiano de Geología.

Shanmugam, G., 2006, Deep-Water Processes and Facies Models: Implications for Sandstone Petroleum Reservoirs: Amsterdam, Elsevier, $476 \mathrm{p}$.

Vinnels, J. S., Butler, R. W. H., McCaffrey, W. D., Paton, D. A., 2010. Depositional processes across the Sinú Accretionary Prism, offshore Colombia. Marine and Petroleum Geology 27, 794-809. 
Table 1 - Seismic facies table. Description of seismic facies associated to the mass transport deposits identified in the study area.

\begin{tabular}{|c|c|c|c|c|}
\hline \multirow{4}{*}{ Type } & \multicolumn{4}{|c|}{ S e i s m i c f a c i e s } \\
\cline { 2 - 5 } & SF1 & $\begin{array}{c}\text { Description } \\
\text { Migh-amplitude reflections } \\
\text { with a highly chaotic } \\
\text { pattern }\end{array}$ & $\begin{array}{c}\text { Debris-flow deposits and slump } \\
\text { blocks in a mud matrix }\end{array}$ \\
\cline { 2 - 5 } Mass Transport \\
Complex
\end{tabular}

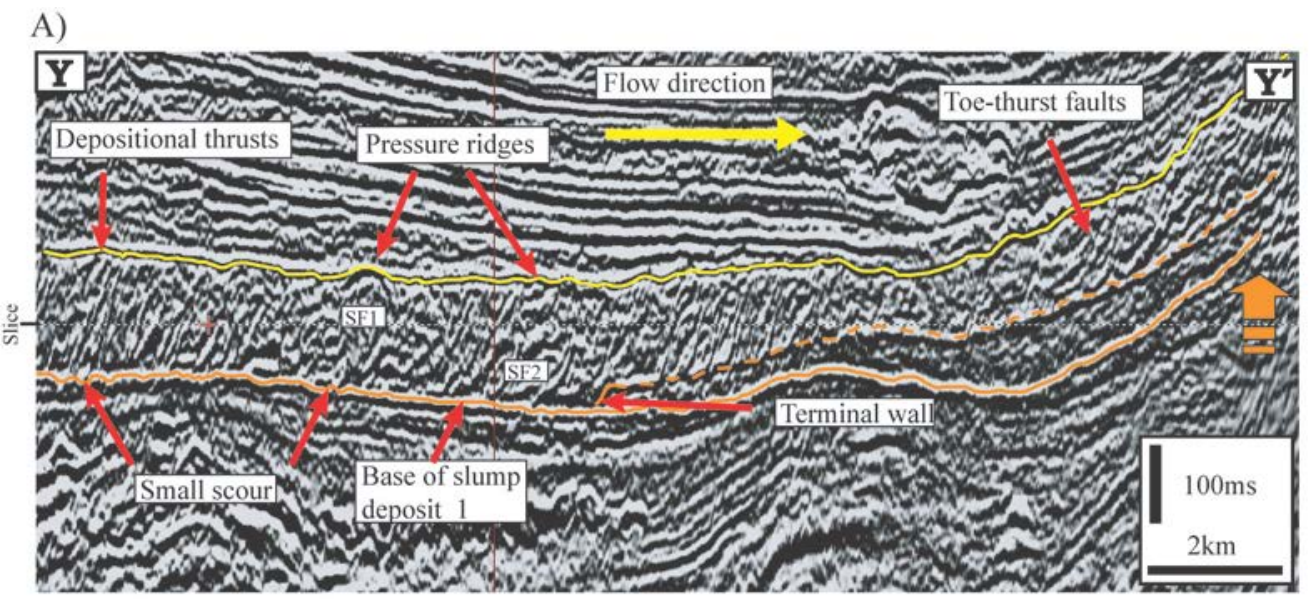

Figure 2. - Depositional thrusting related to slumping

B)

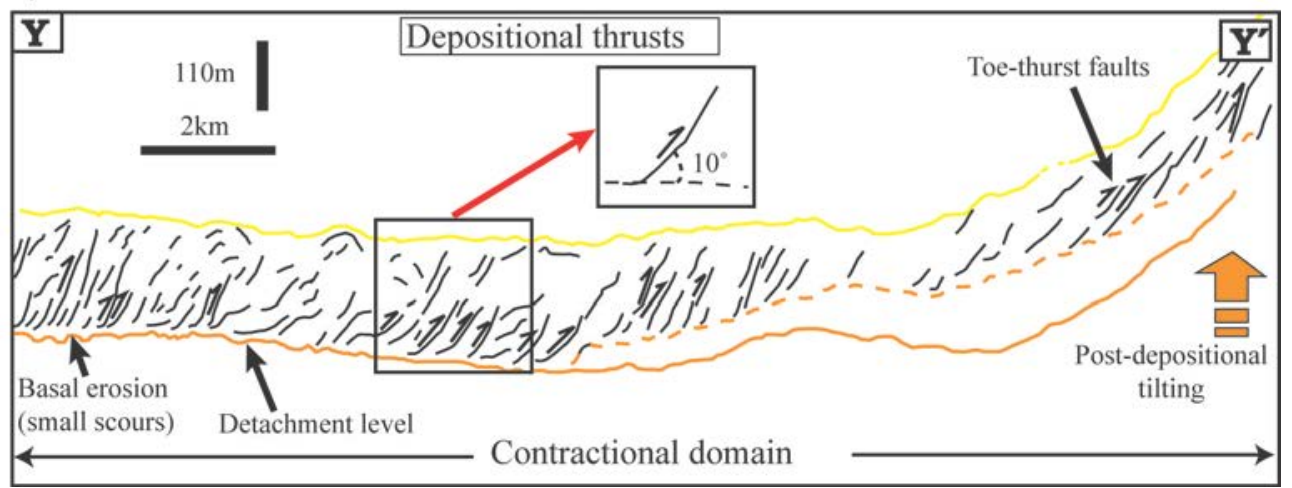



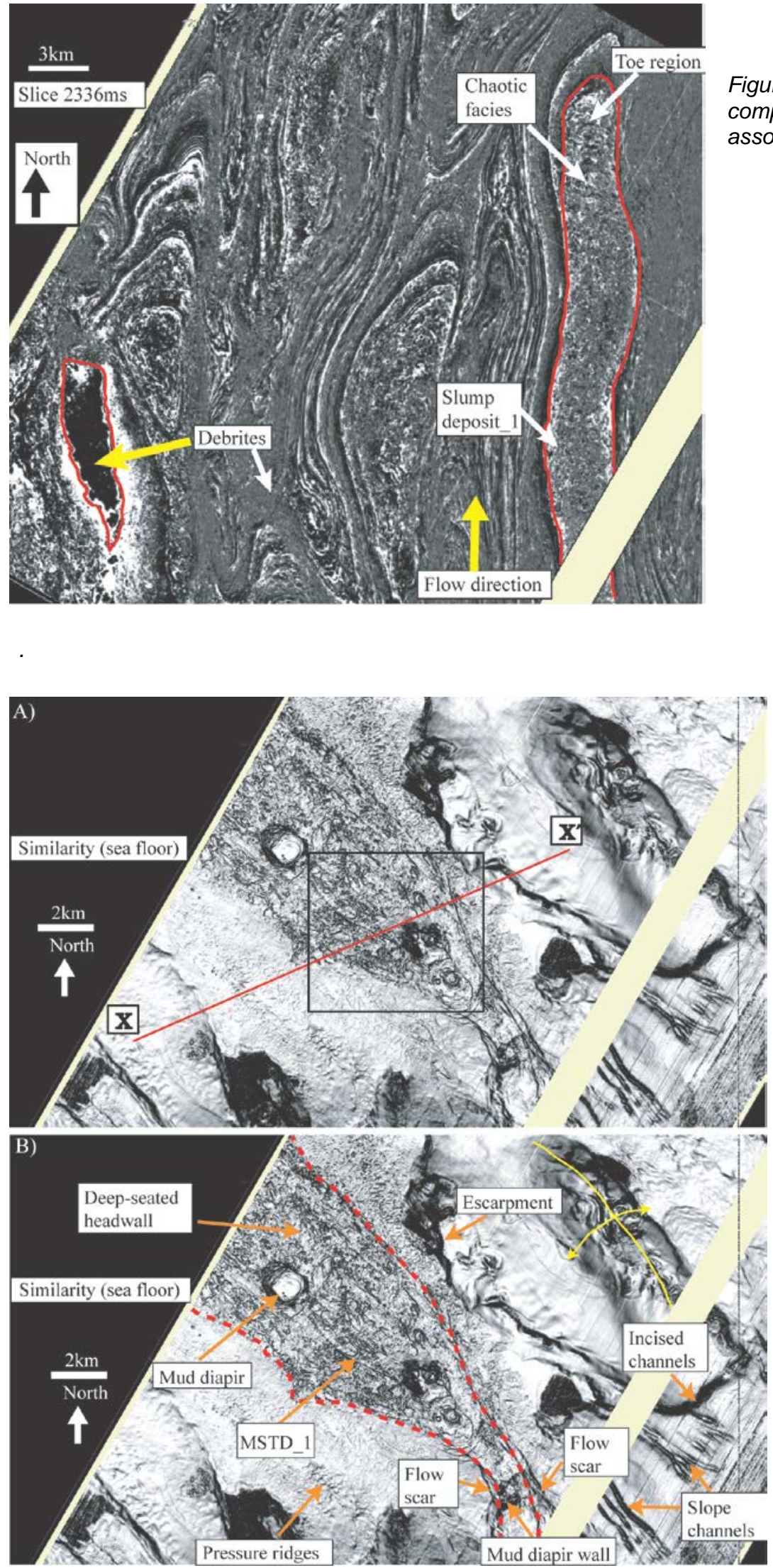

Figure 3 - Slumps and debrites as shown by complex trace attribute. There are a toe region associated to the terminal zone of the slump
Figure 4 - Similarity in sea floor. A) Uninterpreted similarity showing location of profile $\left.X X^{\prime} . \quad B\right)$ Mixed slumps-turbiditesdebrites and associated structures and depositional elements. 